\title{
COMPARISON OF THE KEELER PULSAIR 2000 NON-CONTACT TONOMETER WITH GOLDMANN APPLANATION
}

\author{
MERRICK J. MOSELEY ${ }^{1}$, JOHN R. THOMPSON ${ }^{2}$, JOHN DEUTSCH ${ }^{3}$, GARY P. MISSON ${ }^{1}$, GERALD \\ NAYLOR ${ }^{3}$, ANNE TAN-YEE $^{3}$, ROBERT H. TAYLOR $^{3}$ and ALISTAIR R. FIELDER ${ }^{1}$ \\ Birmingham and Leicester
}

\begin{abstract}
SUMMARY
The Pulsair 2000 non-contact tonometer (Keeler Ltd, UK) is compared with the Goldmann applanation tonometer. Data from 80 eyes were acquired by four experienced observers. A linear regression analysis showed the relationship between the instruments to be: Pulsair=0.66 + 0.95 Goldmann. Individual components of variation were analysed by analysis of variance which indicated a significant variation in the slope of the regression equation due to observers $(p=0.02)$ but not to the order in which topical anaesthesia was administered. Differences between two Pulsair instruments were of marginal significance $(p=0.07)$. The intercept of the regression equation was unaffected by any of the components of variation. Seventy-nine per cent of averaged intraocular pressure measurements obtained with the Pulsair 2000 fell on or within $\pm 3 \mathrm{mmHg}$ of those measured with the Goldmann tonometer. It is concluded that the Pulsair 2000 can provide clinically useful measurements of intraocular pressure.
\end{abstract}

Intraocular pressure (IOP) is commonly measured with instruments which require mechanical contact with the cornea. Non-contact tonometry, first introduced by Grolman, ${ }^{1}$ is an alternative method in which corneal applanation is produced by an air pulse. Advantages of non-contact tonometry include the lack of any requirement for corneal anaesthesia and the minimisation of infection risks (though the latter has been disputed ${ }^{2}$ ).

Whilst the Goldmann tonometer remains the clinical 'gold standard', non-contact tonometers are now well

From: 'Department of Ophthalmology, University of Birmingham, Birmingham and Midland Eye Hospital, Birmingham; ${ }^{2}$ Department of Ophthalmology, University of Leicester, Clinical Sciences Building, Leicester Royal Infirmary, Leicester; and ${ }^{3}$ Birmingham and Midland Eye Hospital, Birmingham, UK.

Correspondence to: Dr. Merrick J. Moseley, Academic Unit, Birmingham and Midland Eye Hospital, Church Street, Birmingham B3 2NS, UK. established and in particular the performance of the Keeler Pulsair has been widely reported. ${ }^{2-17}$ In this instrument, measurement of IOP is derived from the air pressure required to produce an applanation event. The precise moment of applanation is transduced by optical means from changes in corneal reflection. Unlike other noncontact tonometers, the Pulsair is hand-held allowing measurements to be obtained in the upright and supine positions. Specialist applications have included glaucoma screening, ${ }^{15,18}$ peri-operative IOP measurement ${ }^{5,19}$ and paediatric ophthalmic assessment. ${ }^{20,21}$

The Keeler Pulsair is calibrated against a large sample of Goldmann applanation measurements and several authors have sought to establish the accuracy of this instrument in relation to their own samples of PulsairGoldmann comparisons. ${ }^{3,4,6,7,9,11-13,15,17}$ These studies have generally commented favourably on the accuracy of the Pulsair, though several have identified a tendency of the instrument to underestimate the Goldmann tonometer at high pressures. ${ }^{3,7,12,13,17}$

In 1991, Keeler introduced a modified instrument (the 'Pulsair 2000') incorporating several ergonomic improvements to the original. Up to 10 pressure readings can now be automatically averaged and stored in memory; thus users need no longer pause between readings to record the pressure manually. Readings can be rapidly obtained as realignment is not required between each measurement. In contradistinction to the original instrument, a single (revised) calibration negates the requirement to switch ranges when pressures exceed $30 \mathrm{mmHg}$. A preliminary evaluation $^{22}$ over the pressure range $9-27 \mathrm{mmHg}$ concluded that the Pulsair 2000 represented a significant improvement in accuracy over the original instrument.

The purpose of the present study is to evaluate the new instrument's accuracy with reference to standard Goldmann tonometry used in clinical practice. 
Table I. Summary of experimental design

Order A: Anaesthesia $\longrightarrow$ Pulsair $\longrightarrow$ Goldmann $\longrightarrow$ Pulsair Order B: Pulsair $\longrightarrow$ Anaesthesia $\longrightarrow$ Goldmann $\longrightarrow$ Pulsair

\section{METHODS}

Measures of IOP were obtained from 160 patients attending, or receiving inpatient care at the Birmingham and Midland Eye Hospital. The predominant diagnoses were glaucoma suspect, and primary open-angle glaucoma. Ages ranged from 14 to 91 years.

All measurements were undertaken by four experienced observers (J.D., G.P.M., G.N. and R.H.T.). Four early production Pulsair 2000 instruments were employed, each observer performing 10 measurements with each. Ethical permission was granted by the District Ethical Committee of West Birmingham Health Authority. Informed consent was obtained from all subjects.

Relevant patient details were recorded on a study pro forma. On obtaining verbal informed consent, the observer randomly selected one eye for measurement. The operation of the Pulsair 2000 was demonstrated by 'firing' a test pulse on to the subject's hand. Next, a series of four readings was obtained from the study eye followed immediately by a series of four Goldmann applanation readings using a recently calibrated Haag-Streit AG Goldmann tonometer. Finally, four further Pulsair 2000 readings were obtained. Topical anaesthesia (oxybuprocaine $0.4 \%$ ) and fluorescein staining was undertaken in one half of the study eyes before the initial Pulsair 2000 readings (order A) and after the initial Pulsair 2000 readings in the remaining study eyes (order B). This experimental design is summarised in Table I. No subject had measurements obtained from more than one eye, or by more than one observer.

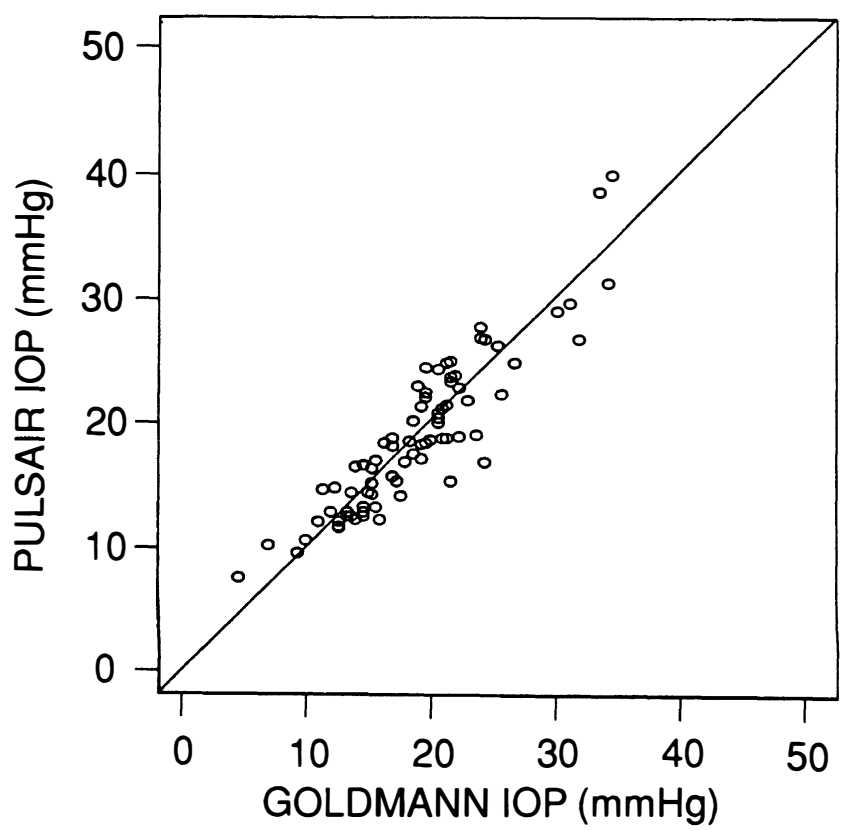

Fig. 1. Scatterplot of Goldmann against Pulsair 2000 IOP measurements. Line of unity indicates perfect agreement.
Following the manufacturer's recommendations, each series of Pulsair readings was averaged to give a single IOP measurement. The individual Goldmann readings were similarly averaged, with the first reading excluded in line with recommended clinical practice. ${ }^{23}$ To compensate for the fall in IOP generally observed during repeated tonometry, ${ }^{24}$ all reported comparisons are between the averaged Goldmann readings and the combined average of Pulsair readings obtained before and after Goldmann applanation.

On completion of the trial, the four Pulsair 2000s were returned to the manufacturer to undergo quality control checks currently applied to commercially available instruments. Two Pulsairs were found to be unrepresentative of instruments currently being marketed and data from these have been excluded from the analysis.

Data were analysed by linear regression and hence the comparison is based on the assumption that the Goldmann tonometer gives the exact IOP. ${ }^{25}$ Analysis of variance was performed using the statistical package SAS and gives the type III sums of squares and corresponding tests. ${ }^{26}$

\section{RESULTS}

Averaged pressures determined with the Goldmann tonometer ranged from 4.7 to $34.3 \mathrm{mmHg}$ (mean 18.7, SD 6.0). The relationship between the measured Goldmann and Pulsair pressures for the 80 study eyes is shown in Fig. 1. The regression line is: Pulsair $=0.66+0.95$ Goldmann. A transformation of the data ${ }^{27}$ to account for the apparent variability did not significantly alter the parameters of the regression equation. The $95 \%$ confidence interval for the intercept is $(-1.17,2.50)$ and for the slope is $(0.85,1.04)$. The residual variation has a standard deviation of $2.52 \mathrm{mmHg}$.

The difference between Pulsair and Goldmann pres-

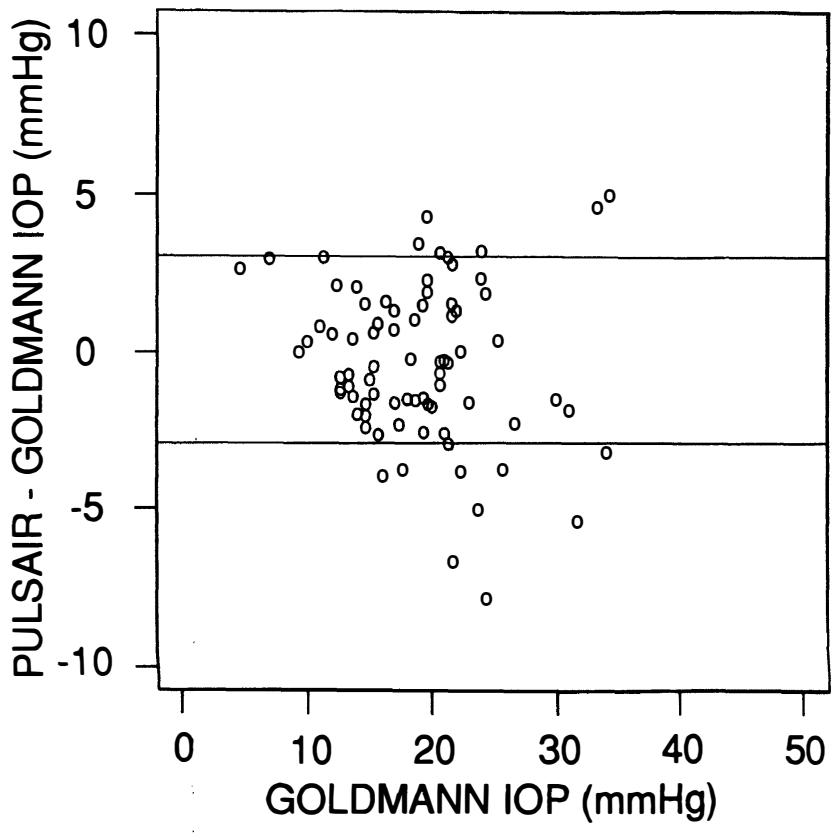

Fig. 2. Difference plot of Pulsair 2000 minus Goldmann IOP measurements against Goldmann IOP. Horizontal lines indicate $a \pm 3 \mathrm{mmHg}$ bandwidth. 
Table II. Analysis of variance

\begin{tabular}{lrrrrl}
\hline Source & d.f. & \multicolumn{1}{c}{ SS } & \multicolumn{1}{c}{ MS } & VR & $p$ value \\
\hline Observer & 3 & 21.0 & 7.0 & 1.5 & 0.21 \\
Machine & 1 & 10.4 & 10.4 & 2.3 & 0.13 \\
Order (anaesthesia) & 1 & 0.3 & 0.3 & 0.1 & 0.80 \\
Goldmann & 1 & 1359.4 & 1359.4 & 300.1 & 0.0001 \\
Observer $\times$ Goldmann & 3 & 48.5 & 16.2 & 3.6 & 0.02 \\
Machine $\times$ Goldmann & 1 & 15.1 & 15.1 & 3.3 & 0.07 \\
Order $\times$ Goldmann & 1 & 4.7 & 4.7 & 1.1 & 0.31 \\
Residual & 68 & 308.1 & 4.53 & & \\
\hline
\end{tabular}

sures is plotted against Goldmann pressure in Fig. 2. This shows that $60 \%$ of the measurements differed by $\leqslant 2 \mathrm{mmHg}$ and $79 \%$ by $\leqslant 3 \mathrm{mmHg}$.

The standard deviations within the series of Pulsair and Goldmann readings were: first four Pulsair readings, $2.73 \mathrm{mmHg}$; Goldmann readings (3), $1.04 \mathrm{mmHg}$; last four Pulsair readings, $2.39 \mathrm{mmHg}$. Pooling the two Pulsair estimates gives a standard deviation of $2.56 \mathrm{mmHg}$. Since the analysis involved average readings, the standard deviation associated with the average of the eight Pulsair readings is $0.91 \mathrm{mmHg}$ and that corresponding to the average of the three Goldman readings is $0.60 \mathrm{mmHg}$. It is clear, therefore, that the residual variation of $2.52 \mathrm{mmHg}$ found from the simple linear regression includes sources of variation over and above the inherent variability in the measurements.

The components of variation were further investigated by analysis of variance (Table II). There is no evidence of any difference in the intercepts due to the observers, machines or timing of anaesthesia ('order'). However, the slope does appear to differ with observer $(p=0.02)$ and perhaps with machine $(p=0.07)$. The variability in slopes between observers can be attributed to a single individual whose results differed from those of the other three, particularly at high pressures. It is, however, impossible to attribute this to systematically low Pulsair readings or to systematically high Goldmann readings.

The residual standard deviation (ANOVA) is $2.13 \mathrm{mmHg}$ and is still much larger than the inherent variability of the Goldmann and Pulsair instruments. There are therefore other unexplained sources of variability. One factor may be the difficulty of comparing a central Goldmann measurement with the average of two surrounding Pulsair series; IOP declined from the first to the second series of Pulsair measurements on average by $1.6 \mathrm{mmHg}$ (SD $2.8 \mathrm{mmHg}$ ) and any non-linearity in this reduction with respect to time would constitute an unquantified source of variability.

For illustrative purposes, the simple regression, excluding observations by the discrepant observer, is: Pulsair $=-0.51+1.03$ Goldmann. The $95 \%$ confidence interval for the intercept is $(-2.51,1.48)$ and for the slope is $(0.93,1.13)$. The residual standard deviation is $2.41 \mathrm{mmHg}$.

\section{DISCUSSION}

The results of the trial suggest that the Pulsair 2000 is accurately calibrated and provides clinically meaningful measures of IOP comparable to those obtained by Goldmann applanation. Of particular salience is the extent to which measurements obtained with the Pulsair 2000 fall within $\pm 3 \mathrm{mmHg}$ of those obtained with the Goldmann tonometer - a bandwidth which has been considered an acceptable margin of error when comparing candidate tonometers with the Goldmann standard. ${ }^{28}$ In the present case, $79 \%$ of pressures obtained with the Pulsair 2000 fell on or within $\pm 3 \mathrm{mmHg}$ of the averaged Goldmann readings.

To put these figures into perspective it is pertinent to consider previously reported agreement studies for observers using only the Goldmann tonometer. Although high levels of agreement have been shown, ${ }^{29}$ many studies do not indicate unanimity either within or between observers. For example, a figure of $70 \%$ of paired measurements within $\pm 3 \mathrm{mmHg}$ has been reported for inter-observer agreement ${ }^{30}$ - a value exceeded by the intra-observer comparison between different instruments in the present study.

One of the observer's results differed significantly from those of the other three, though it is not possible to attribute this specifically to inappropriate use of one or both tonometers. However, evidence from an as yet unreported study suggests that this observer has a tendency to measure higher on the Goldmann tonometer compared with colleagues of similar experience; this finding accords with the observation that the Goldmann tonometer involves a subjective visual task whilst the Pulsair is in essence an objective instrument.

Timing of anaesthesia (before or after the initial Pulsair series) appeared not to influence IOP measurement: a finding of some importance for those seeking to calibrate noncontact tonometers, not requiring topical anaesthesia, against applanation tonometers which do.

Of further note are the limitations inherent in any attempt to define the comparability of tonometric measurements obtained with different instruments. There is a body of evidence ${ }^{24,31-36}$ including that of the present study, showing that repeated tonometry causes a shortterm reduction in IOP. Should this occur in a non-linear fashion $^{31}$ then attempts to define the comparability between methods will always be confounded, irrespective of study design.

The authors wish to acknowledge the support of Mr. P. J. McDonnell, Mr. E. C. O'Neill and Mr. G. R. Kirkby. This research was funded in its entirety by Keeler UK Limited. None of the authors has any proprietary interest in the Pulsair 2000 tonometer. M.J.M. and J.R.T. are consultants to Keeler UK Limited.

Key words: Goldmann applanation tonometry, Intraocular pressure, Non-contact tonometry, Pulsair 2000, Tonometry.

\section{REFERENCES}

1. Grolman B. A new tonometer system. Am J Optom Arch Am Acad Optom 1972;49:646-66.

2. Britt JM, Clifton BC, Barnebey HS, Mills RP. Microaerosol formation in noncontact 'air-puff' tonometry. Arch Ophthalmol 1991;109:225-8. 
3. Armstrong TA. Evaluation of the Tono-Pen and the Pulsair tonometers. Am J Ophthalmol 1990;109:716-20.

4. Bonomi L, Baravelli S, Cobbe C, Tomazzoli L. Evaluation of Keeler Pulsair non-contact tonometer: reliability and reproducibility. Graefes Arch Clin Exp Ophthalmol 1991; 229:210-12.

5. Bricker SRW, McGalliard JN, Mostafa SM. The Keeler Pulsair air impulse tonometer. Anaesthesia 1990;45:36-9.

6. Choi WJ, Kim JW, Tchah H, Jin YH, Kim YJ. Non-contact tonometry: an ideal method for mass screening. Korean $\mathbf{J}$ Ophthalmol 1990;4:30-3.

7. Climenhaga H, Plucinska H. Comparison of the Pulsair noncontact tonometer and the Goldmann applanation tonometer. Can J Ophthalmol 1989;24:7-9.

8. Draeger J, Rumberger E, Dauper J, Deutsch C. Microprocessor controlled tonometry. Eye 1989;3:738-42.

9. Fisher JH. Watson PG, Spaeth G. A new handheld air impulse tonometer. Eye 1988;2:238-42.

10. Lagerlöf O. Airpuff tonometry versus applanation tonometry. Acta Ophthalmol (Copenh) 1990;68:221-4.

11. Langmann G, Schumann G, Langmann A, Zenz H. Zur Tonometrie mit einem neuen non contact-tonometer. Klin Monatsbl Augenheilkd 1990;197:393-6.

12. Moseley MJ, Evans NM, Fielder AR. Comparison of a new non-contact tonometer with Goldmann applanation. Eye 1989;3:332-7.

13. Sponsel WE, Kaufman PL, Strinden TI, DePaul KL, Bowes $\mathrm{HN}$, Olander KW, Barnebey HS. Evaluation of the Keeler Pulsair non-contact tonometer. Acta Ophthalmol (Copenh) 1989;67:567-72.

14. Schwartz R, Draeger J, Wirt H, Runberger E, Dauper J, Deutsch C. Untersuchungen zur klinischen Brauchbarkeit neuer Tonometer. Fortschr Ophthalmol 1990;87:41-4.

15. Rouhiainen $\mathrm{H}$, Teräsvirta $\mathrm{M}$. Incidence of open-angle glaucoma and screening of the intraocular pressure with a noncontact tonometer. Acta Ophthalmol (Copenh) 1990;68: 344-6.

16. Wirt H, Draeger J, Rumberger E, Deutsch C, Dauper J. Vergleichende Untersuchungen zur Kalibrierung neuartiger elektronisch-automatischer Tonometer. Fortschr Ophthalmol 1989;86:403-6.

17. Yucel AA, Sturmer J, Gloor B. Vergleichende Tonometrie mit dem Keeler Luft-impuls non contact-tonometer "Pulsair" und dem Applanationstonometer nach Goldmann. Klin Monatsbl Augenheilkd 1990;197:329-34.

18. Vernon SA. Screening for glaucoma in the community by non-ophthalmologically trained staff using semiautomated equipment. Eye 1990;4:89-97.
19. Vernon S. Non-contact tonometry in the postoperative eye. Br J Ophthalmol 1989;73:247-9.

20. Kohl P, Sabre M, Samek M. Intraocular pressure measurements in children (birth-5 years of age) using the Keeler Pulsair non-contact tonometer. Invest Ophthalmol Visual Sci 1989;30 (Suppl):241.

21. Buscemi M, Capoferri C, Garavaglia A, Nassivera C, Nucci P. Noncontact tonometry in children. Optom Vis Sci 1991; 68:461-4.

22. Pearce CD, Kohl P, Yolton RL. Clinical evaluation of the Keeler Pulsair 2000 tonometer. J Am Optom Assoc 1992; 63:106-10.

23. Haag-Streit AG. Ophthalmological Instruments. Use of the Goldmann applanation tonometer, Nr. 1029 M-2240.

24. Motolko MA, Feldman F, Hyde M, Hudy D. Sources of variability in the results of applanation tonometry. Can J Ophthalmol 1982; 17:93-5.

25. Moseley MJ, Shaw DE. Method-comparison studies: the Keeler Pulsair tonometer. Anaesthesia 1990;45:515.

26. SAS Institute Inc. SAS user's guide: statistics, version 5. Cary, NC: SAS Institute Inc., 1985.

27. Chatterjee S, Price B. Regression analysis by example. New York: Wiley, 1974.

28. Kao SF, Lichter PR, Bergstrom TJ, Rowe S, Musch DC. Clinical comparison of the Oculab Tono-Pen to the Goldmann applanation tonometer. Ophthalmology 1987;94: $1541-4$.

29. Thorburn W. The accuracy of clinical applanation tonometry. Acta Ophthalmol 1978;56:1-5.

30. Phelps CD, Phelps GK. Measurement of intraocular pressure: a study of its reproducibility. Albrecht von Graefes Arch Klin Exp Ophthal 1976;198:39-43.

31. Bechrakis E. Über den spontanen Druckabfall bei Applanationstonometrie. Ophthalmologica 1966;151:604-14.

32. Goldmann H. Some basic problems of simple glaucoma. Am J Ophthalmol 1958;48:213-46.

33. Krakau CET, Wilke K. On repeated tonometry. Acta Ophthalmol (Copenh) 1971;49:611-14.

34. Moses RA. Repeated applanation tonometry. Ophthalmologica 1961;142:663-8.

35. Stocker F. On changes in intraocular pressure after application of the tonometer. Am J Ophthalmol 1958;45:192-6.

36. Wilke K. Effects of repeated tonometry: genuine and sham measurements. Acta Ophthalmol (Copenh) 1972;50: 574-82. 